\title{
Identification of Antibiotic-Resistant Bacteria in the Primary Health Center in Bandung (Qualitative study in Puskesmas Ibrahim Adjie)
}

\author{
Mayrina Firdayati $^{*}$, Anindrya Nastiti $^{1}$, Marlia Singgih $^{2}$, Elin Julianti ${ }^{2}$, Muhammad Azhari ${ }^{2}$, and Didit \\ Trihartomo ${ }^{1}$ \\ ${ }^{1}$ Faculty of Civil and Environmental Engineering, Institut Teknologi Bandung, Indonesia \\ ${ }^{2}$ Pharmacochemistry Department, School of Pharmacy, Institut Teknologi Bandung
}

\begin{abstract}
The world is currently facing a serious health threat resulting from antimicrobial resistance (AMR). It is estimated that the global mortality related to AMR is roughly 700,000 per year and is expected to rise to 10 million annually by 2050 . Healthcare facilities are among the main contributors of antimicrobial resistance. This study aims to identify the existence of antibiotic resistance bacteria in the air environment of the primary health facility (Puskesmas). Ten samples were collected in 4 different places of indoor environment in Puskesmas Ibrahim Adjie, Bandung, West Java. Antibiotic resistance bacteria (ARB) first selected by growing in 5 different selective media. There are 265 colonies which then selected and identified respectively by using Kirby-Bauer Method with Amoxicillin and Microgen Biochemical Identification. Three dominant bacteria Stenotrophomonas (Xanthomonas) maltophilia, Pseudomonas stutzeri and Serratia marcescens, were found. Those bacteria are not the main pathogenic bacteria but recently recognized as opportunistic pathogen combining a propensity for healthcare-associated infection and antimicrobial resistance.
\end{abstract}

\section{Introduction}

The world is currently facing a serious health threat resulting from increasing antibiotic-resistance bacteria (ARB) infections. The Welcome Trust [1] estimated that global mortility related to antimicrobial resistance (AMR) is to be near 700,000 per year and is expected to rise to 10 million annually by 2050 . It will accompany with economic burden of 100 trilion. AMR started with the unregulated use of antimicrobials in the human health, veterinary medicine, and production sectors. In Indonesia, self-medication with antibiotic or the use of non-prescribed antibiotics is common. A populationbased survey in Yogyakarta city showed a potential increase in self-medication with antibiotics for treatment of minor symptomps such as common cold and headache among Indonesians, particularly in urban areas. The 4week period prevalence of self medication with antibiotics was $7.3 \%$. The most widely used antibiotics is amoxicillin [2]. Beside high rates of self-medication, common and unnecessary prescription of antibiotics by physicians and over-the-counter purchase of antibiotics are common as well.

Misuse and overuse of antibiotics exerts pressure of selection on pathogen populations that encourage the development of resistance and exchange of resistance genes. The loss of effective antibiotic treatment reduce the ability of healthcare professional to fight infectious diseases and manage their complications. WHOS's Global Antimicrobial Surveillance System (known as GLASS) show occurence of antibiotic resistance among 500 thousand people with suspected bacterial infections across 22 countries [3]. The most commonly resistant bacteria were Acinetobacter spp., Escherichia coli, Klebsiella pneumoniae, Neisseria gonorrhoeae, Salmonella spp., Shigella spp., Staphylococcus aureus, and Streptococcus pneumoniae.

In Indonesia, limited researches have been done for detecting ARB in human. Bacteria such as Streptococcus pneumoniae, E.coli, Staphylococcus aureus, Salmonella typhi, Klebsiella sp., Proteus mirabilis, Proteus vulgaris and Pseudomonas aeruginosa have been found resistant to various kinds of single antibiotics. Some of them also classified as multidrug resistant bacteria or resistant to more than one kind of antibiotic [4-6]

Based on some studies, the main contributors of antimicrobial resistance dissemination are animal husbandries, wastewater treatment plants and hospitals[7]. Until now, there is no data about antibiotic resistance bacteria presence in environmental media including water, soil and air in Indonesia. Then, it necessary for initiate research about antibiotics resistance bacteria in environment.

Airborne microbials can move directly, from person to person through respiration, ingestion and dermal contact or indirectly, from waste handling and loading of

* Corresponding author: mayrina@tl.itb.ac.id 
sewage, biosolids or animal wastes. This study taking samples from indoor air environment in one health facility such as primary health facility (called Puskesmas) in Bandung, Indonesia. The aim of this qualitative study to identify the existence of antibiotic resistance bacteria in air environment of the primary health facility.

\section{Materials and Methods}

\subsection{Sampling}

Air samples were collected in Puskesmas Ibrahim Adjie in Bandung city, within 3 different days and from four rooms (Table 1), using air sampler attached with five type of selective agar media plates (Table 2). The health centre was located in Batununggal sub-district, known as one of heterogenous community in Bandung. Selective media was used to selectively targeted certain bacteria such as Pseudomonas aeruginosa, Staphylococcus aureus, Escherichia coli, Salmonella, and Enterococci.

Table 1. Room type

\begin{tabular}{|c|c|}
\hline Room & Code \\
\hline Waiting Room 1st floor & WR1 \\
\hline Waiting Room 2nd floor & WR2 \\
\hline Emergency room & ER \\
\hline Delivery room & DR \\
\hline
\end{tabular}

Table 2. Selective Medium and Target Bacteria

\begin{tabular}{|c|c|}
\hline Medium & Organism \\
\hline $\begin{array}{c}\text { XLDA } \\
\text { (Xylose Lysine Deoxycholate A } \\
\text { gar) }\end{array}$ & $\begin{array}{c}\text { Klebsiella, } \\
\text { Salmonella }\end{array}$ \\
\hline CETA (Cetrimide Agar) & $\begin{array}{c}\text { Pseudomonas } \\
\text { aeruginosa }\end{array}$ \\
\hline VJA (Vogel Johnson Agar) & $\begin{array}{c}\text { Staphylococcus } \\
\text { aureus }\end{array}$ \\
\hline VRBA (Violet Red Bile Agar) & $\begin{array}{c}\text { coli-aerogenes } \\
\text { bacterial group }\end{array}$ \\
\hline MCA (MacConkey Agar) & $\begin{array}{c}\text { E.coli, Shigella } \\
\text { (Enterobacteriaceae) }\end{array}$ \\
\hline
\end{tabular}

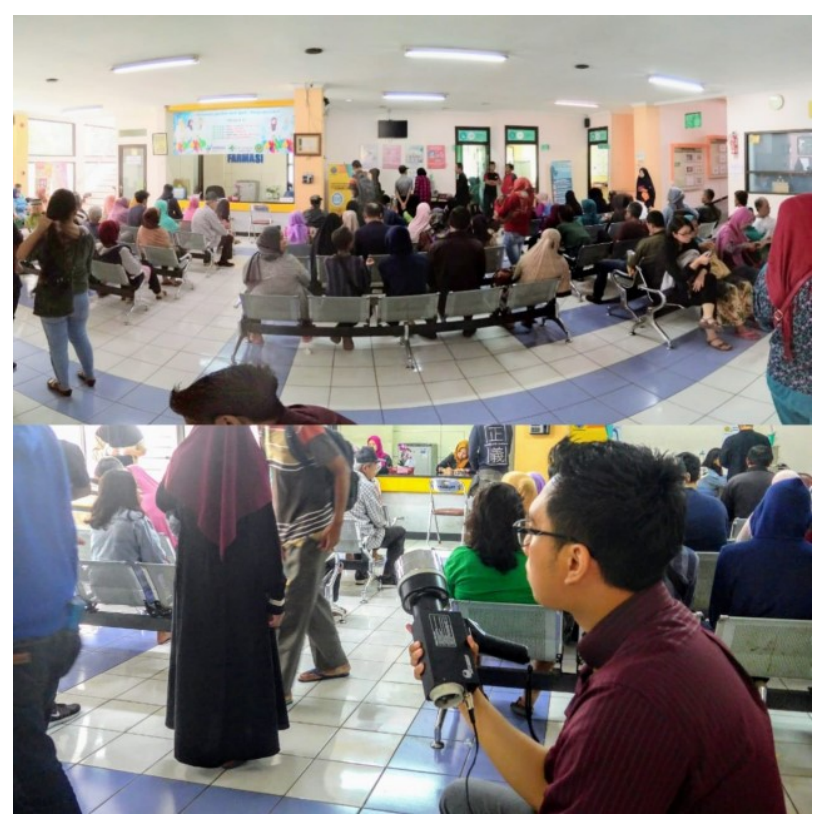

Fig. 1. Sampling activity (Waiting Room $1^{\text {st }}$ floor)

Sampling situation was shown in Figure 1. Five hundred (500) liters of air sample were used for one type of selective media. Then, the plates were incubated in $37{ }^{\circ} \mathrm{C}$ incubator for 24 hours. Colonies growth in media then prepared for isolation (Figure 2). Sampling was conducted in January 2019.

\subsection{Bacteria Isolation}

Variation of colonies from selective media plates were isolated using four quadrant streak methods. The isolation was performed until pure colonies were obtained and confirmed by microscopic (Gram staining) and macroscopic analysis. The pure bacteria isolates were kept in Nutrient Agar slants for downstream analysis.

\subsection{Antibiotic Susceptibility Test}

Antibiotic susceptibility test was done using agar diffusion method (Figure 3). Pure isolates were screened for their susceptibility against antibiotic, in this matter, amoxicillin. Test bacteria (pure isolates) were prepared by inoculating in Mueller-Hinton Broth (MHB) and incubated for 24 hours. The bacteria suspension then diluted to reach $0.08-0.13$ absorbance using UV-Vis spectrophotometer at $625 \mathrm{~nm}$ (equal to $0.5 \mathrm{McF}$ arland). Once the absorbance requirement was fulfilled, $100 \mu \mathrm{L}$ was mixed with Mueller-Hinton Agar (MHA) at 45-50 ${ }^{\circ} \mathrm{C}$ in sterile plate and gently rotated to ensure even dissemination. Once the MHA solidified, paper discs containing amoxicillin $25 \mu \mathrm{g}$ were put on the surface of the MHA agar plate. Each plate contained three antibiotic disc (triplicates). Then, all plates were incubated in the $37{ }^{\circ} \mathrm{C}$ incubator for 24 hours. After incubation, inhibition zones were measured and each bacterium were categorized as susceptible, intermediate, and resistant. Only isolates categorized in resistant, with diameter $<18 \mathrm{~mm}$ (based on Clinical and Laboratory 
Standard Institute-CLSI) were further analysed to determine their species by using biochemistry characterization analysis and molecular analysis.

\subsection{Bacteria Identification and Confirmation}

The isolated bacteria were then identified by using biochemical test and 16S rRNA molecular marker analysis. The first screening biochemistry characteristic screening was done by using Indol, Methyl Red, VogesProskaeur, Citrate Utilization (IMViC) and TSIA test. The second biochemistry analysis was done using Microgen ID GN-A and GN-B Kit. The biochemistry kit analysis included the analysis of ability to produce lysine decarboxylase, ornithine decarboxylase, $\mathrm{H}_{2} \mathrm{~S}$, urease, ability to hydrolyze ONPG, reduction of nitrate, indole production, acetoin production, citrate utilization, indolepyruvic acid production, proteolytic enzyme production, ability to inhibit conversion of succinic acid to fumaric acid, fermentation of glucose, mannitol, xylose, inositol, sorbitol, rhamnose, sucrose, lactose, arabinose, adonitol, raffinose, alicin, and conversion of arginine.

Further analysis was done using 16S rRNA sequencing with GGATTAGATACCCTGGTA forward primer $(705 \mathrm{~F})$ and CCGTCAATTCMTTTRAGTTT reverse primer (907R), and also bioinformatics analysis to clearly determine ambiguous result of previous biochemistry characterization. Sequence trimming done with Bioedit [8] and sequences contig assembling done using ClustalX version 2.0 [9]. The contiq sequences were compared with $16 \mathrm{~S}$ rRNA database in Genbank using BLAST (Basic local alignment search tool) provided by the National Center for Biotechnology Information Server [10].

\section{Results and Discussion}

Puskesmas Ibrahim Adjie Bandung (PIA) was chosen because one of the 5 biggest primary health centre, sometimes known as Community Health Centres, in Bandung, West Java with visitor around 100 people per day. It open 6 days a week from 7 am to $4 \mathrm{pm}$. The PIA building consists of two floors with 11 service clinics. The first floor is occupied by a number of health polyclinics such as General Clinics, Young Toddler Disease Management, Tuberculosis clinic, Laboratory, Emergency Room, Delivery Room, and Pharmacy. On the second floor there is Dental Clinic, Family Planning Service, Underfive Young Toddler (Balita) Service, Mother Child Service, and Counseling room. The PIA also equipped with wastewater treatment plant facilities. Accredited as first level Puskesmas (Utama) with complete facilities as primary health centre. It made the PIA visited by variety age, diseases and community even far away from their service area such as from Bandung Regency. Waiting rooms $1^{\text {st }}$ and $2^{\text {nd }}$ floor was selected for sampling places because they become gathering place of patients before meeting with the doctor and non patient who accompanied the patient, as well. While delivery room and 24 hrs emergency room are the place that is expected as main area of pathogen bacteria exposure if compare with other rooms in the health centre.

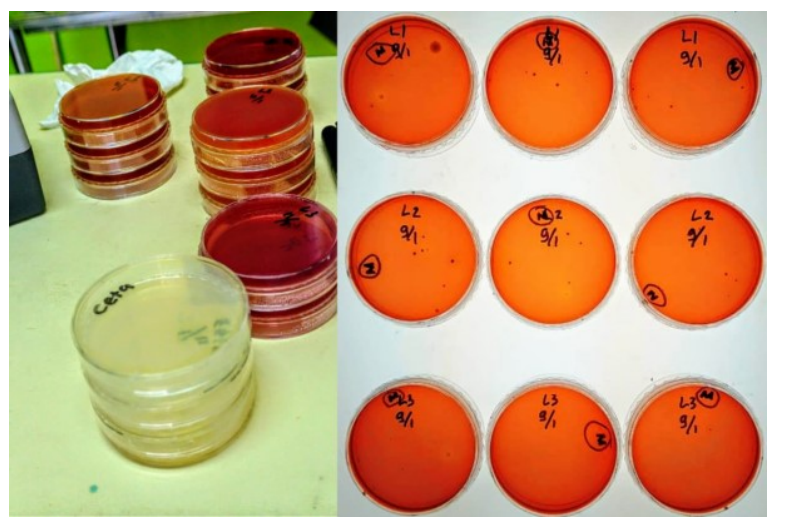

Fig. 2. Medium used for sampling (left) \& growth after incubation (right).

Table 3 show amount of colony that can grow in the specific selective medium. All the selective media that is used are the common media for clinical specimens. There are 464 colonies from four different media, with $72,8 \%$ of them grew in Mac Conkey Agar, 20\% from Vogel Johnson Agar, 5 \% from Violet Red Bile Agar and the rest in Xylose Lysine Deoxycholate Agar. Most of the bacteria colonies that grow have been isolated from waiting room especially from first floor. This room is used as waiting room for almost all activities in the health centre from registration to doctor's, laboratory and pharmacy queue. It also exposed to outdoor environment of the Puskesmas that placed on the side of busy main road.

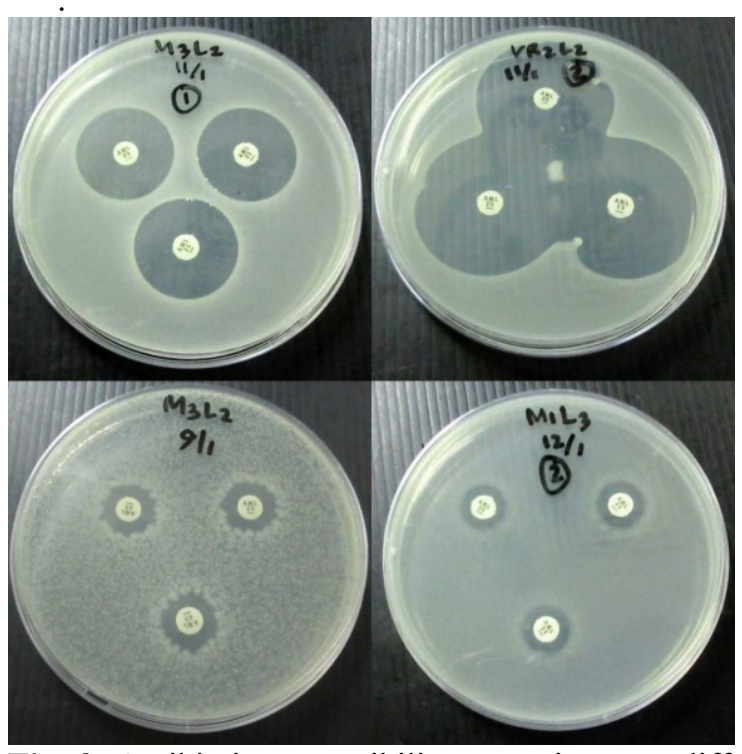

Fig. 3. Antibiotic susceptibility test using agar diffusion method. 
From all isolates that test with amoxicillin, 40 pure colonies then identified as gram positive and gram negative which has inhibition zone less than $18 \mathrm{~mm}$ and showed amoxicillin resistance. All the bacteria that was found in XLDA medium had grown with inhibition zone $26,5 \mathrm{~mm}-34,9 \mathrm{~mm}$ and was not categorized as resistant colony.

All presumptive colonies then identified and confirmed with 2 level biochemistry test. We found Serratia marcescens and Stenotrophomonas (Xanthomonas) maltophila as confirmed bacteria. Three cultures from three different medium then further identified with $16 \mathrm{~S}$ rRNA sequencing and bioinformatics analysis which confirmed as Pseudomonas stutzeri (Pseudomonas stutzeri ATCC 17588 = LMG 11199 16S ribosomal RNA, complete sequence, with 99\% query cover and 0 E-value). It was interesting that from selective medium for Pseudomonas, Cetrimide Agar, we cannot find any bacteria growth in it. But, from other medium, VJA, VRBA and MCA, the isolates were identified and confirmed as Pseudomonas stutzeri.

Pseudomonas stutzeri is an anerobic, nonfermenting, a gram-negative and nonfluorescent denitrifying bacterium. It is mostly a saprophyte found in soil and water. $P$. stutzeri is also ubiquitous in hospital environment, so, this species could be considered an opportunistic but rarely leads to serious community or nosocomial acquired infections [11]. Like most Pseudomonas spp, it can grow in minimal, chemically defined media with ammonium ions or nitrate and single organic molecule as the sole carbon and energy source. Some $P$. stutzeri strains can grow diazotrophic, this charasteristic seems to be rare among the genus Pseudomonas. P. stutzeri has also been isolated as an opportunistic pathogen from human. Some literatures showed that when P. stutzeri is isolated from clinical material it most likely represents colonization in hospitalized patients and uncommonly indicates pathogenicity. During the past decade, there is a significant increase of $P$. stutzeri isolations from clinical material in medical center[11]. The most common reported sites of clinical isolates are surgical wounds, blood, respiratory tract, and urine. Human cases of $P$. stutzeri infection are rare, but some researchs recorded and related it with some cases of infective endocarditis, bone infection, bacteremia, meningitis, pneumonia and induced peritonitis in patients undergoing continuous ambulatory peritoneal dialysis (CAPD) [12-14].
So far, there is no cases reported about $P$. stutzeri infection in human in Indonesia, but it caused an outbreak of freshwater fish in Luwuk Banggai (tilapia and catfish), Bali (tilapia), Jambi (tilapia and catfish) and Tanjung Pinang (catfish)[15].

Summary of sensitivity test for several antibiotics with P.stutzeri was written by Lalucat et al[11]. Nearly all studies showed that P.stutzeri was sensitive to many more antibiotics than P.aeruginosa which is most closely related species and well known as human pathogen. Exclusion, if bacteria isolate were obtained from immunosuppressed patients. Even though, resistant $P$. stutzeri strains have been isolated for almost all antibiotic families, including amoxicillin, with the exception of fluoroquinolones. This suggests that $P$. stutzeri has a wide range of antibiotic resistance mechanisms, at least two mechanisms (i) alterations in outer membrane proteins and lipopolysaccharide profiles and (ii) the presence of $\beta$-lactamase that hydrolize natural and semisynthetic penicillins, broad-spectrum $\beta$-lactamase-stable cephalosporins, and monobactams with similar rates.

Serratia marcescens is gram-negative bacilli and a member of the genus Serratia which is a part of the family Enterobacteriaceae. It occupy various habitats, mainly water, plants, soil, small mammals and hospitalized patients as well.Once considered a harmless saprophyte, Serratia marcescens is now recognized as an important opportunistic pathogen combining a trend for healthcare-associated infection and antimicrobial resistance. S. marcescens causes both opportunistic and nosocomial infections, and frequent source of outbreak of hospital infection in both adult and paediatric patients. It has been demonstrated to be involved in respiratory and urinary tract infections, bacteremia, septicemia, meningitis, ocular and wound infections, pneumonia, endocarditis, and septic arthritis [16,17]. Infection of $S$.marcescens has been attributed to medical equipment such as nebulisers, bronchoscopes, laryngoscopes, electrocardiogram leads, and contaminated solution including inhalation medications and antiseptics. Environmental sources such as air conditioning units, urine-collecting basins, liquid soap dispensers and even tap water have been implicated as well. Moreover, outbreak among newborn in neonatal intensive care (NICU) and nursery has happened in Saudi Arabia due to S.marcescens-contaminated baby shampoo [17].

Table 3. Amount of bacterial colony growth in selective medium

\begin{tabular}{|c|c|c|c|c|c|c|c|c|c|c|}
\hline \multirow{2}{*}{$\begin{array}{c}\text { Selective } \\
\text { Medium }\end{array}$} & \multicolumn{9}{|c|}{$\begin{array}{c}\text { Total Colony } \\
\text { Fliting Room 1st }\end{array}$} & \multicolumn{2}{c|}{$\begin{array}{c}\text { Waiting Room 2nd } \\
\text { Floor (WR2) }\end{array}$} & \multicolumn{2}{c|}{$\begin{array}{c}\text { Emergency Room } \\
\text { (ER) }\end{array}$} & $\begin{array}{c}\text { Delivery Room } \\
\text { (DR) }\end{array}$ \\
\cline { 2 - 11 } & $\begin{array}{c}\text { Fatch } \\
\mathbf{1}\end{array}$ & $\begin{array}{c}\text { Batch } \\
\mathbf{2}\end{array}$ & $\begin{array}{c}\text { Batch } \\
\mathbf{3}\end{array}$ & $\begin{array}{c}\text { Batch } \\
\mathbf{1}\end{array}$ & $\begin{array}{c}\text { Batch } \\
\mathbf{2}\end{array}$ & $\begin{array}{c}\text { Batch } \\
\mathbf{3}\end{array}$ & $\begin{array}{c}\text { Batch } \\
\mathbf{1}\end{array}$ & $\begin{array}{c}\text { Batch } \\
\mathbf{2}\end{array}$ & $\begin{array}{c}\text { Batch } \\
\mathbf{3}\end{array}$ & $\begin{array}{c}\text { Batch } \\
\mathbf{3}\end{array}$ \\
\hline XLDA & 2 & 0 & 0 & 1 & 0 & 0 & 1 & 0 & 0 & 0 \\
\hline CETA & 0 & 0 & 0 & 0 & 0 & 0 & 0 & 0 & 0 & 0 \\
\hline VJA & 0 & 19 & 14 & 3 & 21 & 34 & 0 & 3 & 2 & 3 \\
\hline VRBA & 5 & 6 & 1 & 2 & 5 & 4 & 0 & 3 & 0 & 0 \\
\hline MCA & 23 & 79 & 46 & 19 & 73 & 30 & 3 & 29 & 22 & 14 \\
\hline
\end{tabular}




\begin{tabular}{|c|c|c|c|c|c|}
\hline \multirow{2}{*}{ No. } & \multirow{2}{*}{ Antibiotic } & \multicolumn{4}{|c|}{ Antibiotic Consumption } \\
\hline & & 2014 & 2015 & 2016 & 2017 \\
\hline \multirow{5}{*}{1} & \multicolumn{5}{|l|}{ Amoxicilin } \\
\hline & Amoxicilin capsule $250 \mathrm{mg}$ & ND & 914000 & 5921300 & 1051900 \\
\hline & Amoxicilin caplet $500 \mathrm{mg}$ & 3514800 & 3076300 & 170600 & 1073900 \\
\hline & Amoxicilin dry syrup $125 \mathrm{mg} / 5 \mathrm{ml}$ (bottle) & 85358 & 68264 & 11710 & 33812 \\
\hline & Amoxicilin dry syrup $250 \mathrm{mg} / 5 \mathrm{ml}$ (bottle) & 2700 & ND & ND & 14525 \\
\hline \multirow{5}{*}{2} & \multicolumn{5}{|l|}{ Chloramphenicol } \\
\hline & Chloramphenicol capsule $250 \mathrm{mg}$ & 98700 & 85300 & 97900 & 16000 \\
\hline & Chloramphenicol capsule $500 \mathrm{mg}$ & ND & ND & ND & 33900 \\
\hline & Chloramphenicol syrup $125 \mathrm{mg} / 5 \mathrm{ml}$ (bottle) & ND & ND & ND & 2110 \\
\hline & Chloramphenicol ear drops 3\% (bottle) & ND & 7656 & 9170 & ND \\
\hline 3 & Tetracycline capsule $250 \mathrm{mg}$ & 85200 & 78600 & 90600 & 57700 \\
\hline 4 & Cefixim tablet $100 \mathrm{mg}$ & 1470 & ND & ND & 28890 \\
\hline 5 & Erytromycin $250 \mathrm{mg}$ & 1100 & ND & ND & 4200 \\
\hline 6 & Ciprofloxacin $500 \mathrm{mg}$ & 214000 & ND & ND & 122100 \\
\hline \multirow{3}{*}{7} & \multicolumn{5}{|l|}{ Clindamycin } \\
\hline & Clindamycin capsule $150 \mathrm{mg}$ & 177350 & ND & ND & 55250 \\
\hline & Clindamycin capsule $300 \mathrm{mg}$ & 31700 & ND & ND & 81100 \\
\hline
\end{tabular}

-Source : Health Profile Report of Bandung City in 2014, 2015, 2016 and 2017

In Indonesia, research about existence S.marcescens in hospital patient has been reported. It was found in the specimens of patient treated in both NICU and ICU $[19,20]$. Important finding from some studies showed the predominant mode of spread of S.marcescens is hand-tohand transmission by hospital or healthcare workers [21]. S.marcescens renowned for its ability to exhibit multiple antimicrobial resistance. Studied of old and current strain of S.marcescens showed that all strains were resistant to penicillin $\mathrm{G}$, ampicillin, amoxicillinclavulanic acid, cefazolin, cefamandole, polymixin B, colistin, rifampicin, glycopeptides, fusidic acid, lincosamides, streptogramins, daptomycin, linezolid and cefuroxime[16].

Stenotrophomonas maltophilia is a gram-negative bacteria that common found in aqueous habitat, such as water, food and plant rizosphere. This bacteria now become an emerging multidrug resistant global opportunistic pathogen. The increasing incidence of nosocomial and community-acquired $S$. maltophilia infections is of particular concern for immunocompromised individuals [22]. The organism is commonly found in respiratory tract infections, and also cause of bacterimia, urinary tracts infection, meningitis, serious wound infections, mastoiditis, epididymitis, conjunctivitis and endocarditis[23]. Some research show that $S$. maltophilia was resistent multiple antibiotics, including $\beta$-lactams, aminoglycosides, carbapenems, tetracycline, quinolone and chloramphenicol.

Instead of finding main pathogenic bacteria with specific medium, this study showed presence of three opportunistic pathogen bacteria, Stenotrophomonas (Xanthomonas) maltophilia, stutzeri and Serratia marcescens. They recognized recently and numerous studies revealed that they related to nosocomial infection that commonly come from hospital environment, medical equipment and transmission from healthcare workers. Study also showed that there was tendency of increasing antimicrobial resistant of those three. In Indonesia, Gram negative bacteria that cause nosocomial infection tend to resistant to antibiotic that common use for them [24].

Many studies confirming association between increasing use of antibiotics and enhanced antimicrobial resistance. Total consumption of 7 antibiotic in 75-80 primary health centre and government hospital (from 2014-2017) in Bandung can be seen in Table 4. Amoxicillin is a widely-available and used antibiotic in primary health and hospital. Event not really consistent, there was downward trend in Amoxicillin and Tetracyclin use, the most antibiotic first line treatment, especially after year 2016, but not to other kind of antimicrobial. The overall consumption could be double or more, with additional data from private hospital or pharmacies. The potential risk also increase along with high consumption due to self medication practice in Indonesia.

Then, this research become preliminary study to see potential risk contamination of environment with antimicrobials and antimicrobial-resistant microbes, which can accelerate the development and spread of resistance in Indonesia. This is not only threat for human 
and animal population but also for natural environment. Research of AMR existence in environmental media such as air and especially water be important to address knowledge gaps and evaluate the potential risk antimicrobial and ARBs in the environment poses to human health and the environmental ecosystem[25].

The authors express gratitude to the research fund granted by Research, Community Service, and Innovation Program (Program Penelitian, Pengabdian kepada Masyarakat, dan Inovasi-P3MI) of ITB.

\section{References}

1. The Wellcome Trust, Review on Antimicrobial Resistance. The Review on Antimicrobial Resistance, Tackling Drug-Resistant Infections Globally: Final Report and Recommendations (2016). Available online: https://amrreview.org/sites/default/files/160525_Finalpaper_wi thcover.pdf (accessed on 30 August 2019)

2. A.Widayati, S.Suryawati, C. De Crepigny, J.E.Hiller, BMC Research Notes, 4, 491 (2011)

3. WHO, The Global Antimicrobial Resistance Surveillance System (GLASS) Report: Early Implementation 2017-18 (2017). Available online: https://apps.who.int/iris/bitstream/handle/10665/279 656/9789241515061-eng.pdf?ua $=1$ (accesed on 30 August 2019)

4. Y.E.L.Gaol, Erly, E.Sy, Jurnal Kesehatan Andalas, 6, 1 (2017). In Indonesian language. Available online:

http://jurnal.fk.unand.ac.id/index.php/jka/article/vie w/664 (accessed on 30 August 2019

5. A.E.Erviani, Biogenesis, 1, 1(2013). In Indonesian language. Available online: http://journal.uinalauddin.ac.id/index.php/biogenesis/article/view/447 (accessed on 30 August 2019)

6. H. Parathon, K. Kuntaman, T. H. Widiastoety, B. T. Muliawan, A. Karuniawati, M. Qibtiyah, Z. Djanun, J. F. Tawilah, T. Aditama, V. Thamlikitkul, S. Vong, BMJ, 358; j 3808 (2017)

7. J. Li, J.Cao, YG Zhu, QL Chen,F Shen, Y Wu, S $\mathrm{Xu}, \mathrm{H}$ Fan, G Da, RJ Huan, J Wang, A.L. de Jesus, L.Morawska, C.K.Chan. J.Peccia, M. Yao, Environ.Sci.Technol., 52 (2018)

8. Hall, Tom A. BioEdit: a user-friendly biological sequence alignment editor and analysis program for Windows 95/98/NT. Nucleic acids symposium series. Vol. 41. No. 41. [London]: Information Retrieval Ltd., c1979-c2000., (1999)

9. Larkin, Mark A., et al. Clustal W and Clustal X version 2.0. bioinformatics 23(21), 2947-2948 (2007)

10. Altschul, S. F., Gish, W., Miller, W., Myers, E. W., \& Lipman, D. J., Basic local alignment search tool. Journal of molecular biology 215(3), 403-410 (1990)
11. J. Lalucat, A. Bennasar, R. Bosch, E.GarcíaValdés, and N. J. Palleroni, Microbiol. Mol. Biol. Rev; 70(2), 510-547( 2006)

12. N. Bisharat, T. Gorlachev and Y. Keness, The Open Infectious Diseases Journal, 6, 21-24 (2012)

13. D. Grimaldi, I. Podglajen, A. Aubert, A. BuuHoï, B. Diebold and J. Mainardi, J. Clin. Microbiol. 47(2): 503-504 (2009)

14. S.W.Park, J.H. Back, S.W.Lee, J.H.Song, C.H.Shin, G. E. Kim, MJ. Kim, Kidney Res.Clin.Pract. 32,8183(2013)

15. W. N. E. Sariati, Kurniasih , S. Amanu and R. Widayanti, Journal of Agricultural Science and Technology ,B 5, 292-296 (2015)

16. E. Fusté, G. J. Galisteo, L. Jover, T. Vinuesa, T. G. Villa and Mi. Viñas, Future Microbiol., 7(6), 781786 (2012)

17. E. Hau, JD Bouaziz, M. Lafaurie, A Saussine; V. Masson, J. Rausky, M. Bagot, F. Guibal, Cutis., 97(3), E8-E12 (2016)

18. T.A.Madani, S.Alsaedi, L. James, James L, B.S. Eldeek, A.A. Jiman-Fatani, D.Marwan, M.Cudal, M.Macapagal, R.Bahlas, M.Farouq, J.Hosp.Infect., 78(1), 16-19

19. D. Estiningsih, I. Puspitasari, T. Nuryastuti, Jurnal Manajemen dan Pelayanan Farmasi, 6(3), 243-248 (2016)

20. M. Radji, S. Fauziah, N. Aribinuko, Asian Pac. J. Trop. Biomed.,1(1), 39-42 (2011)

21. M. L. Cristina, M. Sartini and A. M. Spagnolo, Int. J. Environ. Res. Public Health 16, 610 (2019)

22. J.S. Brooke, Clin. Microbiol. Rev., 25(1), 2-41 (2012)

23. A. Alonso and J.L. Martinez, Antimicrobial Agents and Chemotherapy, 41(5) , 1140-1142 (1997)

24. B. Chudlori. M.Kuswandi, P.Indrayudha, Pharmacon, 13(2), 70-76 (2012)

25. The Wellcome Trust, U.S Centers for Disease Control and Prevention, the UK Science \& Innovation Network. Initiatives for Addressing Antimicrobial Resistance in the Environment: Current Situation and Challenges. (2018).Available online : https://wellcome.ac.uk/sites/default/files/ antimicrobial-resistance-environment -report.pdf 